\title{
$5 S$ rDNA characterization in twelve Sciaenidae fish species (Teleostei, Perciformes): Depicting gene diversity and molecular markers
}

\author{
Fernanda A. Alves-Costa ${ }^{1}$, Cesar Martins ${ }^{2}$, Fernanda Del Campos de Matos ${ }^{2}$, Fausto Foresti ${ }^{2}$, \\ Claudio Oliveira ${ }^{2}$ and Adriane P.Wasko ${ }^{1}$ \\ ${ }^{1}$ Departamento de Genética, Instituto de Biociências, Universidade Estadual Paulista, Botucatu, \\ SP, Brazil. \\ ${ }^{2}$ Departamento de Morfologia, Instituto de Biociências, Universidade Estadual Paulista, Botucatu, \\ SP, Brazil.
}

\begin{abstract}
In order to extend the genetic data on the Sciaenidae fish family, the present study had the purpose to characterize PCR-generated 5S rDNA repeats of twelve species of this group through PAGE (Polyacrylamide Gel Electrophoresis) analysis. The results showed the occurrence of at least two different 5S rDNA size classes in all the species. Moreover, 5S rDNA repeats of one of the studied species - Isopisthus parvipinnis - were cloned and subjected to nucleotide sequencing and Southern blot membrane hybridization analyses, which permitted to confirm the existence of two major $5 \mathrm{~S}$ rDNA classes. Phylogenetic analysis based on the nucleotide sequences of different $5 \mathrm{~S}$ rDNA repeats of $I$. parvipinnis lead to their separation into two major clusters. These results may reflect the high dynamism that rules the evolution rate of $5 S$ rDNA repeats. The obtained data suggest that $5 S$ rDNA can be useful in genetic analyses to identify species-specific markers and determine relationships among species of the Sciaenidae group.
\end{abstract}

Key words: Sciaenidae, fish, Isopisthus parvipinnis, 5S rDNA, molecular markers.

Received: August 22, 2006; Accepted: May 4, 2007.

\section{Introduction}

The $5 \mathrm{~S}$ ribosomal multigene family ( $5 \mathrm{~S}$ rDNA) of higher eukaryotes is comprised of tandemly repeated units of hundreds to thousands of copies that consist of a highly conserved coding sequence of 120 base pairs (bp) and a variable non-transcribed spacer sequence (NTS) (reviewed in Long and David, 1980). Studies on 5S rDNA organization could provide useful data for the understanding of genome organization and dynamics of repetitive sequences, and also provide genetic markers for the identification of species, subspecies, population, strain, or hybrids (e.g. Martins and Wasko, 2004). Although 5S rDNA repeats have been characterized in several vertebrate species, present data are mostly restricted to mammals and amphibians. To date, few analyses have been conducted on fishes, specially taking into account the great number of species of this group (e.g. Martins and Wasko, 2004).

The Sciaenidae (Perciformes) family contains approximately 70 genera and 270 fish species (Schwarzhans,

Send correspondence to Adriane Pinto Wasko. Universidade Estadual Paulista, Departamento de Genética, Instituto de Biociências, 18618-000 Botucatu, SP, Brazil. E-mail: awasko@ibb.unesp.br.
1993; Nelson, 1994) that are distributed in Indian, Pacific and Atlantic Oceans (Longhurst and Pauly, 1987; Sasaki, 1996). Although Sciaenidae is considered a monophyletic group, a great diversity of body shape and mouth position can be observed in several species, associated with different feeding patterns and life histories (Chao and Musick, 1977). Moreover, most species of the group represent important fishery resources with a high commercial value. However, despite the economic importance and the great species diversity, genetic studies are still scarce in this fish group. The available genetic data refer to molecular population genetic (Turner et al., 1998; Lankford et al., 1999; Gold et al., 2001; Cordes and Graves, 2003; O'Malley et al., 2003; Santos et al., 2003) and phylogenetic analyses (Chao, 1978; Sasaki, 1989; Vinson et al., 2004).

To improve the genetic data on Scianidae fish, the present study characterized the PCR-generated 5S rDNA repeat patterns of twelve species of the group. Moreover, $5 \mathrm{~S}$ rDNA repeats of one of the species - Isopisthus parvipinnis - were cloned and subjected to nucleotide sequencing, Southern blot-membrane hybridization and phylogenetic analyses. 


\section{Materials and Methods}

\section{Fish samples, DNA extraction and PCR}

Samples of twelve different species of the Sciaenidae fish family (Nebris microps, Paralonchurus brasiliensis, Stellifer stellifer, S. rastrifer, S. microps, Isopisthus parvipinnis, Cynoscion jamaicensis, C. virescens, Menticirrhus americanus, Micropogonias furnieri, Ctenosciaena gracilicirrhus, and Larimus breviceps) from Ubatuba (São Paulo State, Brazil) were analyzed.

Genomic DNA was extracted from gill tissue, according to the method described by Wasko et al. (2003). A set of primers (Primer A 5'-TACGCCCGATCTCGTCCGAT C-3' and primer B 5'-CAGGCTGGTATGGCCGTAAG C-3'), corresponding to nucleotides 24-44 and 1-21, respectively, of the $5 \mathrm{~S}$ coding region, were designed from the 5S rRNA sequence of rainbow trout (Komiya and Takemura, 1979) to amplify the 5S rRNA genes and their nontranscribed spacer regions (Martins and Galetti, 1999). PCR amplifications were carried out in a total volume of $50 \mu \mathrm{L}$, using 20-100 ng of genomic template DNA, 150 pmol of each primer, $1.25 \mathrm{mM}$ of each dNTP, 1x PCR buffer containing $1.5 \mathrm{mM} \mathrm{MgCl}_{2}$, and $1 \mathrm{U}$ of Taq DNA polymerase (GE Healthcare Life Sciences), using a PTC200 Programmable Thermal Controller (MJ Research, INC). The optimum cycling times were as follows: $94{ }^{\circ} \mathrm{C}$ ( $5 \mathrm{~min}$ ) denaturation, 35 cycles of $1 \mathrm{~min}$ at $95^{\circ} \mathrm{C}, 30 \mathrm{~s}$ at $63^{\circ} \mathrm{C}$, and $1 \mathrm{~min}$ at $72^{\circ} \mathrm{C}$. A final $5 \mathrm{~min}$ extension was performed at $72{ }^{\circ} \mathrm{C}$. The $5 \mathrm{~S}$ rDNA-PCR products were visualized in $6 \%$ polyacrylamide gels by silver nitrate staining.

\section{Cloning, nucleotide sequencing and sequence analyses}

The PCR products of two DNA samples of Isopisthus parvipinnis were selected to be cloned and sequenced, and to be used in Southern blot-membrane hybridization and phylogenetic analyses, since this species presented the most common banding pattern among the analyzed Sciaenidae fish species, which was also observed in Stellifer microps, Stellifer rastrifer, Cynoscion jamaicensis, and Cynoscion virescens. The PCR products of I. parvipinnis were inserted into pGEM-T (Promega), which was used to transform competent cells of $E$. coli $\mathrm{DH} 5 \alpha$ strain (Invitrogen), according to the manufacturer's instructions. Positive recombinant clones were recovered and stored in $75 \%$ glycerol at $-80{ }^{\circ} \mathrm{C}$ for subsequent analysis. Several clones were sequenced on an ABI Prism 377 automatic DNA sequencer (Applied Biosystems) with DYEnamic ET Terminator Cycle Sequencing (GE Healthcare Life Sciences), following the manufacturer's instructions. Nucleic acid sequences were subjected to BLASTN (Altschul et al., 1990) searches at the National Center for Biotechnology Information (NCBI), and the sequence alignment was performed using the computer program Clustal W (Thompson et al., 1994) and by eye. Neighbor-Joining (NJ) phylogenetic analyses employing the Kimura-two-parameter genetic distance model (Kimura, 1980) were conducted using MEGA version 3.1 software (Kumar et al., 2004). Bootstrap resampling using 1000 replicates (Felsenstein, 1985) was applied to assess support for individual nodes.

\section{Southern blot hybridization}

Genomic DNA samples of Isopisthus parvipinnis $(8 \mu \mathrm{g})$ were completely and partially digested with Hind III. This restriction enzyme was chosen since it cuts once inside the 5S rRNA gene of most teleost fish species (Martins and Wasko, 2004). The digestion products were subjected to $1 \%$ agarose gel electrophoresis and Southern-transferred to a Hybond-N nylon membrane (Southern, 1975). The hybridization of the filter-immobilized DNA was performed using as probes clones containing repeat units of $I$. parvipinnis 5S rDNA. Probe labeling, hybridization and detection steps were performed with the kit ECL-Direct nucleic Acid Labeling and Detection System (GE Healthcare Life Sciences) following the manufacturer's instructions.

\section{Results and Discussion}

PCR amplification of 5S rDNA repeats of twelve Sciaenidae species generated distinct polyacrylamide gel electrophoresis banding patterns (Figure 1). The different sizes of the amplified fragments may reflect the intense dynamism that rules the evolution of the 5S rDNA tandem arrays in the fish genome. As the 5S rDNA repeats consist of a 120 bp conserved coding sequence, the observed differences among several Sciaenidae species is related to the NTS regions that can be extremely variable due to inser-

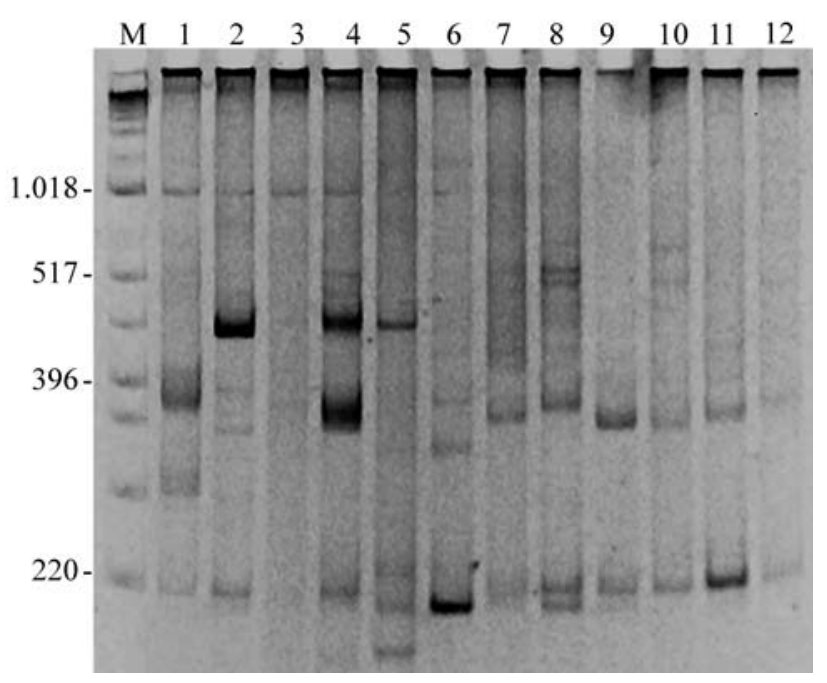

Figure 1 - 5S rDNA PCR products of Sciaenidae species visualized on 6\% polyacrylamide gel: (1) Larimus breviceps, (2) Nebris microps, (3) Paralonchurus brasiliensis, (4) Stellifer stellifer, (5) Menticirrhus americanus, (6) Micropogonias furnieri, (7) S. microps, (8) Ctenosciaena gracilicirrhus, (9) S. rastrifer, (10) Isopisthus parvipinnis, (11) Cynoscion jamaicensis, and (12) C. virescens. M1 and M2 represent molecular mass markers of $1 \mathrm{~kb}$ Plus and $10 \mathrm{bp}$, respectively. The corresponding molecular masses are indicated on the left of the figure. 
IP5S49d TACGCCCGAT CTCGTCCGAT CTCGGAAGCT AAGCAGGGTC AGGCCTGGTT AGTACTTGGA CGGGTGACCG CCTGGGAATA CCAGGTGCTG

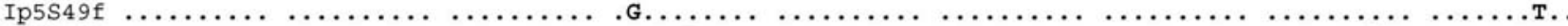

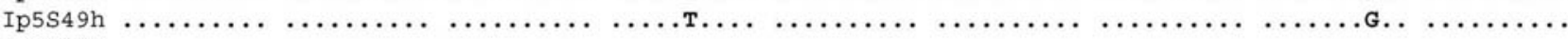

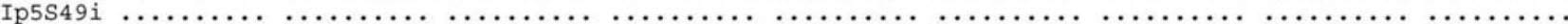

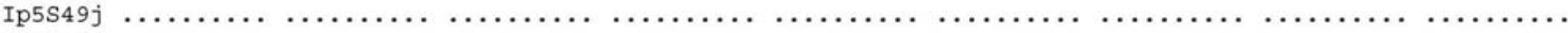

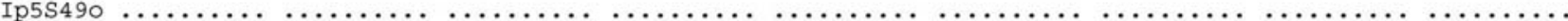

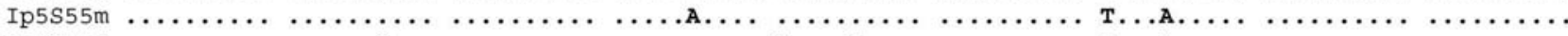

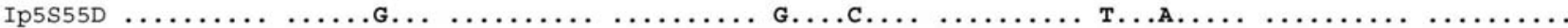

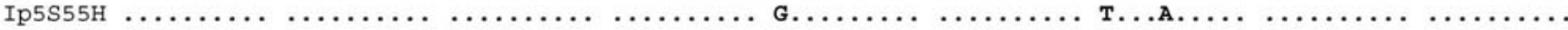
Ip5S49d TAAGCTTTTT CACAAAACCT C-CATCGGCT CCTTCAACGG CCTCGTTGTT G-ATGGATGA CGTACA---C ATAGGCGCCG TTTCTCACCC

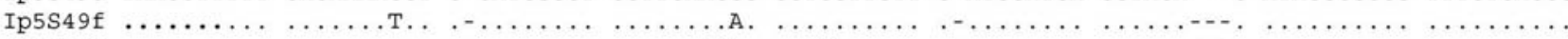

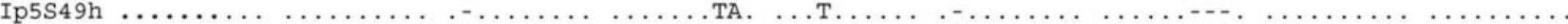

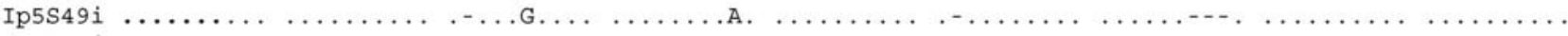

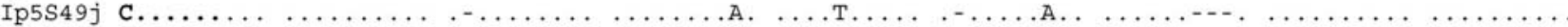

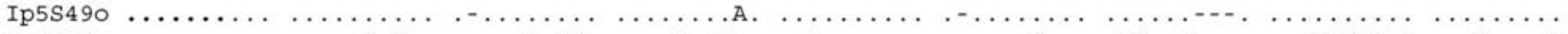

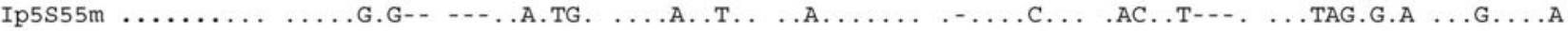
Ip5555D ...........TCCT.T. TG..GA..AC G..G.TGTT. .T..T.G.C. .C.CA.GCAG ..CT..GAA- .C.CTA..A. C..GC..G.. Ip5S55H ........... . TCCT.T. TG..GA..AC G..G.TGTT. .T..T.G.C. .C.CA.GGAG .CT..GAA- .C.C-A.A. C..GC..G.

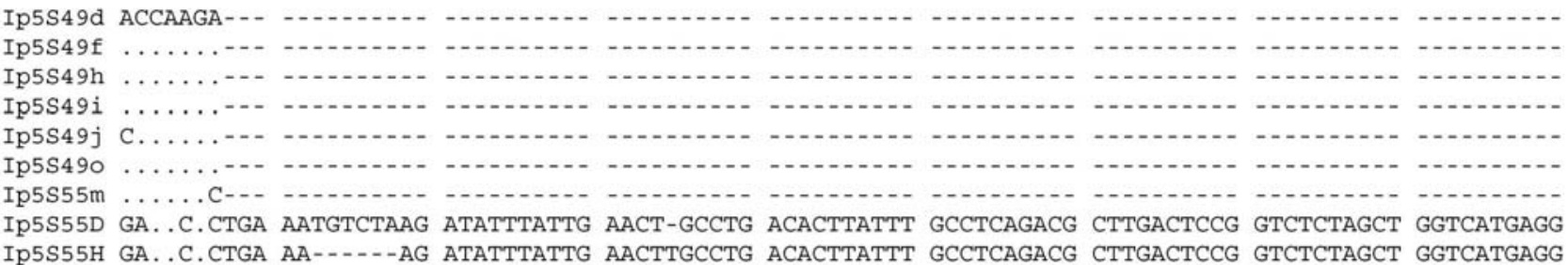

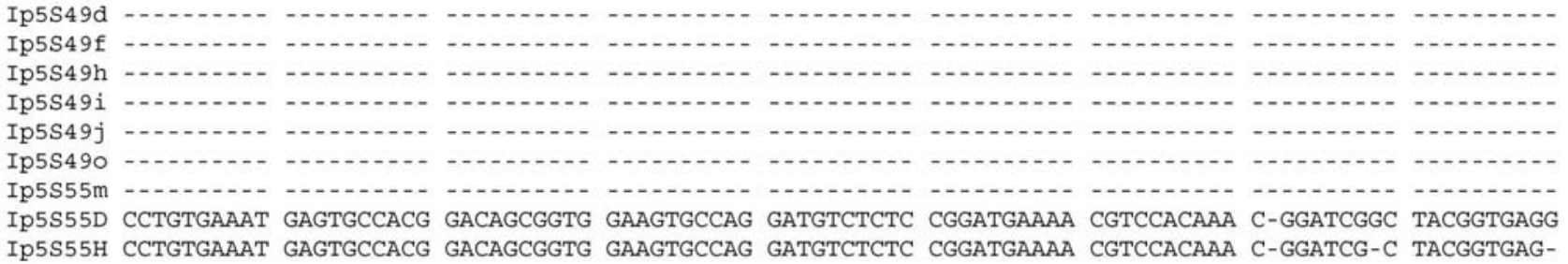

\begin{tabular}{|c|c|c|c|c|c|c|c|c|}
\hline & & 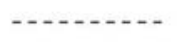 & - - & 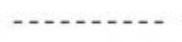 & & & & \\
\hline & - - & 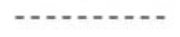 & - & - & $---\ldots$. & & & \\
\hline & - & 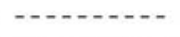 & - & - & $\cdots+\cdots$ & & & \\
\hline & $-\cdots-\cdots$ & 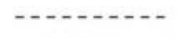 & $\cdots$ & $\cdots-1$ & & & & \\
\hline & 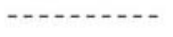 & - & - & $-+-2-1-2$ & & & & \\
\hline & 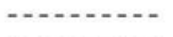 & $-\cdots$ & & $-\cdots+-1$ & $\cdots-\cdots$ & & & \\
\hline & 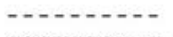 & 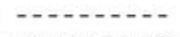 & 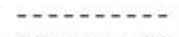 & & & & & \\
\hline & & & ATTTGC & & . & & & \\
\hline & GCGGCCATG & TATAAAT -1 & GTATTTTGC & CTG & TCGTG & & & \\
\hline
\end{tabular}

Figure 2 - Alignment of 5S rDNA nucleotide sequences of Isopisthus parvipinnis. The $5 \mathrm{~S}$ rRNA gene coding sequence is in bold face and the primer regions are underlined. Dots indicate sequence identity, hyphens represent indels.

tions/deletions, minirepeats, and pseudogenes (Nelson and Honda, 1985; Leah et al., 1990; Sajdak et al., 1998).

On the other hand, it was possible to identify similar 5S rDNA amplification patterns for some species of the same genus, such as Stellifer microps and S. rastrifer, and Cynoscion jamaicensis and C. virescens (Figure 1). Moreover, Isopisthus parvipinnis also presented a PCR amplification pattern that resembles the pattern evidenced for the four former species (Figure 1). It was also possible to note that the amplified fragments obtained for Stellifer stellifer were very similar to the ones obtained for Nebris microps (Figure 1). Similar sized 5S-PCR products may reflect a higher genetic similarity among some Sciaenidae species, as already evidenced for other fish (e.g. Wasko et al.,
2001). However, we could not discard the possibility that similar DNA fragment sizes may also present large nucleotide differences. Although mitochondrial DNA sequence analysis has shown a distant relationship between Cynoscion and Stellifer (Vinson et al., 2004), previously published morphometric data (Aguirre and Shervette, 2005) are in accordance with the present results that suggest a closer relationship between these two genera.

Despite the greater resemblance in the 5S rDNA PCR products of Steliffer microps, S. rastrifer, Cynoscion jamaicensis, C. virescens, and Isopisthus parvipinnis, all the other studied Sciaenidae species presented unique 5S rDNA amplification banding patterns, leading to the identification of species-specific DNA markers. 5S rDNA PCR 
amplified products clearly discriminate other fish species, such as the Atlantic salmon (Salmo salar), the brown trout (Salmo truta), and their hybrids (Pendás et al., 1995). Several species of the genus Brycon (Wasko et al., 2001), and Solea solea and Reinhardtius hippoglossoides (Céspedes et al., 1999) also show 5S rDNA PCR species-specific patterns. PCR amplification of 5S rDNA repeats thus represents a potential and simple methodology that can be applied to identify several fish species.

PAGE analysis of the $5 \mathrm{~S}$ rDNA PCR products also showed at least two amplified fragments for all the Sciaenidae species. Each fragment could correspond to a distinct 5S rDNA class, as already detected for other fish species through PCR electrophoresis and nucleotide sequencing analyses (Martins and Galetti, 2001; Martins and Wasko, 2004). Although the occurrence of two distinct 5S rDNA classes represents the most common feature in fish (Martins and Wasko, 2004), some species may also present more than two 5S rDNA types, as shown for some of the analyzed Sciaenidae species with three or more clearly distinct PCR generated fragments (Figure 1).

In order to characterize the $5 \mathrm{~S}$ rDNA nucleotide sequence and genomic organization for one of the analyzed species and also to verify the occurrence of two distinct classes of this repetitive ribosomal DNA in Sciaenidae fish, the two amplified fragments of Isopisthus parvipinnis - with around 200 and 400 base pairs - were cloned, sequenced, and subjected to Southern blot-membrane hybridization and phylogenetic analyses. The nucleotide sequencing analysis of these two fragments supports the existence of two different 5S rDNA size classes, named 5S rDNA type I (201-205 bp) and 5S rDNA type II (413-426 bp) (Figure 2). Both classes showed a conserved 120 bp 5S rRNA gene sequence and a variable NTS ranging between $80 \mathrm{bp}$ (5S rDNA type I) to $280 \mathrm{bp}$ ( $5 \mathrm{~S}$ rDNA type II). These variations were characterized by insertions/deletions, and base substitutions. These 5S rDNA classes were separated in the phylogenetic analysis in $100 \%$ of the generated trees (Figure 3). Yet, one single sequence of 5S rDNA type I was quite different and could be considered a subclass since it appeared separated in $98 \%$ of the generated trees (Figure 3). Although the occurrence of two 5S rDNA repeat classes represents the most common feature in fishes (Martins and Galetti 2001; Martins and Wasko 2004), the presence of variant subclasses also seems to be frequent in this vertebrate group. The presence of two major repeated 5S rDNA classes in I. parvipinnis was confirmed by Southern blot hybridization which revealed the presence of tandem repeats of 200 and $400 \mathrm{bp}$, in agreement with the PCR products and the nucleotide sequencing data (Figure 4).

We take these results as reflecting the high dynamism that governs the evolution rate of the $5 \mathrm{~S}$ rDNA repeats in the genome of Isopisthus parvipinnis and also in other Sciaenidae species. Moreover, the present data indicate that $5 \mathrm{~S}$ rDNA can be useful for general and applied genetic

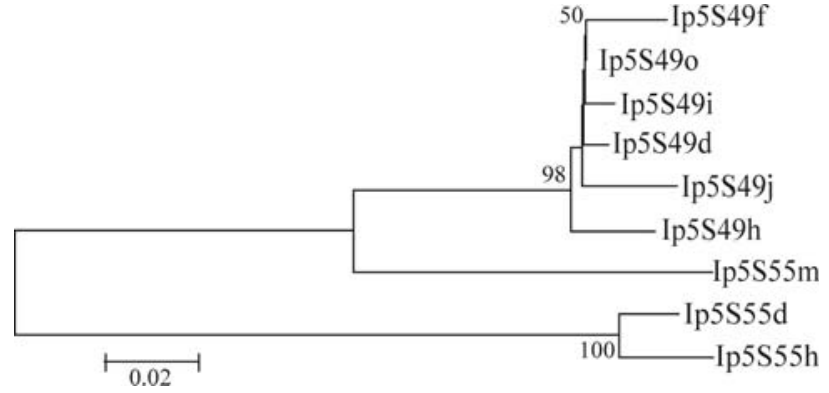

Figure 3 - Neighbor-joining three based on the 5S rDNA nucleotide sequences of Isopisthus parvipinnis. The numbers at each node indicate the percentage recovery $(>50 \%)$ of the particular node (1000 bootstrap replicates).

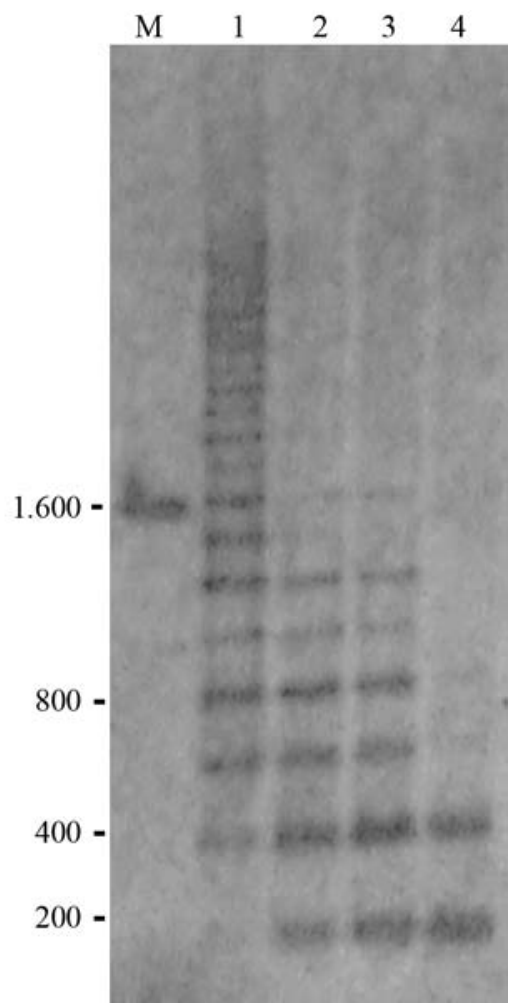

Figure 4 - Southern blot hybridization results of 5S rDNA sequences to genomic DNA of Isopisthus parvipinnis digested with HindIII endonuclease 1, 2 and 3 are partially digested genomic DNA samples (10, 30 and 60 min digestion, respectively), and 4 is a totally digested DNA sample. M, molecular mass marker (bp).

analyses of different sciaenids, in order to identify species-specific markers and determine species relationships.

\section{Acknowledgments}

The authors thank Prof. Dr. Adilson Fransozo for providing the Sciaenidae samples, Ms. Ursulla Pereira Souza for samples identification, and Dr. Anderson L. Alves for helpful assistance in DNA sequencing. This research was supported by grants from FAPESP (Fundação de Amparo à Pesquisa do Estado de São Paulo) and CNPq (Conselho Nacional de Desenvolvimento Científico e Tecnológico). 


\section{References}

Aguirre WE and Shervette VR (2005) Morphological diversity of the Cynoscion group (Perciformes, Sciaenidae) in the Gulf of Guayaquil region, Ecuador: A comparative approach. Environ Biol Fish 73:403-413.

Altschul SF, Gish W, Miller W, Myers EW and Lipman DJ (1990) Basic local alignment search tool. J Mol Biol 215:403-410.

Céspedes A, Garcia T, Carrera E, Gonzalez I, Fernandez A, Hernández PE and Martin R (1999) Identification of sole (Solea solea) and greenland halibut (Reinhardtius hippoglossoides) by PCR amplification of the 5S rDNA gene. J Agric Food Chem 47:1046-1050.

Chao NL and Musick JA (1977) Early life history, functional morphology and feeding habits Sciaenidae of York River, Virginia. Fish Bull 75:657-702.

Chao NL (1978) A basis for classifying Western Atlantic Sciaenidae (Teleostei, Perciformes). NMFS Technical Reports 415:1-64.

Cordes JF and Graves JE (2003) Investigation of congeneric hybridization in and stock structure of weakfish (Cynoscion regalis) inferred from analyses of nuclear and mitochondrial DNA loci. Fish Bull 101:443-450.

Felsenstein J (1985) Confidence limits on phylogenies: An approach using the bootstrap. Evolution 39:783-791.

Gold JR, Burridge CP and Turner TF (2001) A modified stepping-stone model of population structure in red drum, Sciaenops ocellatus (Sciaenidae), from the northern Gulf of Mexico. Genetica 111:305-317.

Kimura M (1980) A simple method for estimating evolutionary rate of base substitution through comparative studies of nucleotide sequences. J Mol Evol 16:111-120.

Komiya H and Takemura S (1979) Nucleotide sequence of 5S ribosomal RNA from rainbow trout (Salmo gairdnerii) liver. J Biochem 86:1067-1080.

Kumar S, Tamura K and Nei M (2004) MEGA 3: Integrated software for molecular evolutionary genetics analysis and sequence alignment. Brief Bioinform 5:150-163.

Lankford TE, Targett TE and Gaffney PM (1999) Mitochondrial DNA analysis of population structure in the Atlantic croaker, Micropogonias undulates (Perciformes, Sciaenidae). Fish Bull 97:884-890.

Leah R, Frederiksen S, Engberg J and Sorensen PD (1990) Nucleotide sequence of a mouse $5 \mathrm{~S}$ rRNA variant gene. Nucleic Acids Res 18:7441.

Long ED and David ID (1980) Repeated genes in eukaryotes. Annu Rev Biochem 49:727-764.

Longhurst AR and Pauly D (1987) Ecology of Tropical Ocean. Academic Press Inc., San Diego, 407 pp.

Martins C and Galetti Jr PM (1999) Chromosomal localization of 5S rDNA genes in Leporinus fish (Anostomidae, Characiformes). Chrom Res 7:363-367.

Martins C and Galetti Jr PM (2001) Two 5S rDNA arrays in Neotropical fish species: Is it a general rule for fishes? Genetica 111:439-446.

Martins C and Wasko AP (2004) Organization and evolution of 5S ribosomal DNA in the fish genome. In: Williams CR (ed) Focus on Genome Research. Nova Science Publishers, Hauppauge, pp 289-318.
Nelson DW and Honda BM (1985) Genes coding for 5S ribosomal RNA of the nematode Caenorhabditis elegans. Gene 38:245-251.

Nelson JS (1994) Fishes of the world. 3rd ed. John Wiley \& Sons Inc., New York, 600 pp.

O'Malley KG, Abbey CA, Ross K and Gold JR (2003) Microsatellite DNA markers for kinship analysis and genetic mapping in red drum, Sciaenops ocellatus (Sciaenidae, Teleostei). Mol Ecol Notes 3:155-158.

Pendás AM, Morán P, Martínez JL and Garcia-Vásquez E (1995) Applications of 5S rDNA in Atlantic salmon, brown trout, and in Atlantic salmon $\mathrm{x}$ brown trout hybrid identification. Mol Ecol 4:275-276.

Sadjak SL, Reed KM and Phillips RB (1998) Intraindividual and interspecies variation in the $5 \mathrm{~S}$ rDNA of coregonid fish. $\mathrm{J}$ Mol Evol 46:680-688.

Santos S, Schneider H and Sampaio I (2003) Genetic differentiation of Macrodon ancylodon (Sciaenidae, Perciformes) populations in Atlantic coastal waters of South America as revealed by mtDNA analysis. Genet Mol Biol 26:151-161.

Sasaki K (1989) Phylogeny of the family Sciaenidae, with notes on its zoogeography (Teleostei, Perciformes). Mem Fac Fish Hokkaido Univ 36:1-137.

Sasaki K (1996) Sciaenid fishes of the Indian Ocean (Teleostei, Perciformes). Mem Fac Sci Kochi Univ Ser D (Biol) 16/17:83-95.

Schwarzhans W (1993) A Comparative Morphological Treatise of Recent and Fossil Otoliths of the Family Sciaenidae (Perciformes), Piscium Catalogus: Part Otolothi Piscium, v. 1. Verlag Dr. Friedrich Pfeil, München, 245 pp.

Southern EM (1975) Detection of specific sequences among DNA fragments separated by gel electrophoresis. J Mol Biol 98:503-517.

Thompson JD, Higgins DG and Gibson TJ (1994) Clustal W: Improving the sensitivity of progressive multiple sequence alignment through sequence weighting, position-specific gap penalties and weight matrix choice. Nucleic Acids Res 22:4673-4680.

Turner TF, Richardson LR and Gold JR (1998) Polymorphic microsatellite DNA markers in red drum (Sciaenops ocellatus). Mol Ecol 7:1771-1788.

Vinson C, Gomes G, Schneider H and Sampaio I (2004) Sciaenidae fish of the Caeté River estuary, northern Brazil: Mitochondrial DNA suggests explosive radiation for the Western Atlantic assemblage. Genet Mol Biol 27:174-180.

Wasko AP, Martins C, Wright JM and Galetti Jr PM (2001) Molecular organization of 5S rDNA in fishes of the genus Brycon. Genome 44:893-902.

Wasko AP, Martins C, Oliveira C and Foresti F (2003) Nondestructive genetic sampling in fish, an improvement method for DNA extraction from fish fins and scales. Hereditas 138:161-165.

\section{Internet Resources}

National Center for Biotechnology Information (NCBI) (http:www.ncbi.nlm.nih.gov/blast).

\section{Associate Editor: Pedro Manoel Galetti Junior}

License information: This is an open-access article distributed under the terms of the Creative Commons Attribution License, which permits unrestricted use, distribution, and reproduction in any medium, provided the original work is properly cited. 